\title{
US to settle dispute over agency jurisdiction
}

Washington

AFTKR months of inter-agency wrangling, the new federal government policy statement on biotechnology research is expected to be published in the Federal Register by the end of the month. Its supporters believe it will make clear the complex maze of regulatory jurisdictions among federal agencies. But even its authors acknowledge that the new document, which is two-and-a-half inches thick, will be a challenge to general understanding.

The framework is the next step in the process begun in December 1984 to coordinate government policy regulating biotechnology (see Nature 313, 85; 1985). Since last November, when an index of relevant statutes appeared in the Federal Register, the Domestic Policy Council (DPC) Working Group on Biotechnology has been conducting an intensive effort to arrive at an inter-agency consensus on how those statutes are to be applied.

"The goal was to get coordination and consistency", says David T. Kingsbury, National Science Foundation (NSF) Assistant Director for Biological, Behavioral and Social Sciences and chairman of the DPC working group. The effort attempts to get away from a process approach to regulation, and move toward a product oriented approach.

The DPC working group felt that placing all products created by recombinant DNA techniques under the same regulatory umbrella was misguided. As an example, the pseudorabies vaccine developed by Saul Kit at Baylor College of Medicine uses a modified virus missing a part of its genome. Because it incorporates no new genetic material, it may reasonably be treated just like any other altered vaccine. The working group takes the approach that it is only when genetic material from organisms of different genera are combined that special attention needs to be paid to the potential hazards of a new organism.

The new document, the Coordinated Framework for Regulation of Biotechnology, contains policy statements by all the major regulatory agencies involved in biotechnology. Because of the "mosaic" of statutes covering biotechnology issues, "the potential for confusion is enormous," says Kingsbury. To ameliorate this problem, the new framework proposes two new definitions as a basis for coordinating new regulations.

The Biotechnology Science Coordinating Committee (BSCC), made up of senior policy officials of agencies involved in biotechnology research and products, took responsibility for coming up with the definitions. An "intergeneric organism (new organism)" is one formed by "delib-

\section{Chernobyl}

\section{British embassies turn monitors}

AN attempt at comprehensive monitoring of the radioactive fallout from the Soviet nuclear accident at Chernobyl has been carried out by British embassies in European capitals bordering the Soviet Union. A statement put out last week by the National Radiological Protection Board and by the Foreign and Commonwealth Office (FCO) suggests that contamination is greatest in north-cast Poland, Czechoslovakia and Hungary.

The FCO statement says, however, that the contamination of local foodstuffs is nowhere high enough to suggest that travellers to those parts of Europe would receive "more than a fraction" of the annual dose limit for members of the general population. The statement adds that travel to Kiev and the western Ukraine. and to Minsk and Byelorussia. should be avoided if possible, but that simple precautions (such as the avoidance of fresh milk and leaf vegetables) would be sufficient elsewhere in the Soviet Union and

\section{Eastern Europe}

The use of the network of British embassies as a means of monitoring fallout from Chernobyl was made possible by the supply of simple equipment immediately after the accident. According to figures accompanying the statement, the doserate at Kiev, south of Chernobyl, had fallen from 30 to 2 microsieverts an hour between the period immediately after the accident and 14 May. Elsewhere in Eastern Europe, the highest dose rates recorded by British embassics were in north-east Poland (4.5 microsieverts an hour) and Romania (3.6 microsieverts an hour), but these had fallen to 0.8 and 0.9 microsieverts an hour by 14 May.

By comparison, the estimated radiation dose rate due to natural causes (cosmic rays, radon and internalized natural radioactive species) is generally taken to be 2 millisieverts a year at normal altitude and in mid-latitude, roughly the equivalent of 0.5 microsieverts an hour. erate combination of genetic material from sources in different genera". A "pathogen" is defined to include microorganisms that "belong to a pathogenic species or that contain genetic material from source organisms that are pathogenic." Specifically excluded from both these definitions are organisms that are "well characterized and contain only noncoding regulatory regions." $\mathrm{BSCC}$ is considering expanding these exemptions, as well as defining more formally an environmental release.

A key accomplishment of the new framework is to sort out the overlapping jurisdications of the various federal agencies involved in biotechnology regulations. The framework attempts where possible to identify the single agency having responsibility for a single product, but where overlapping jurisdictions arise, the lead agency is identified. Kingsbury, as chairman of BSCC and DPC working group, will be the de facto arbiter of disputes over jurisdiction.

While sorting out overlapping jurisdictions between agencies was a major accomplishment for the DPC working group, jurisdictional issues also cropped up within the agencies. At the US Department of Agriculture (USDA), disputes arose between the science and education division and the marketing and inspection services over review issues.

One upshot of the disputes was the creation of an Office of Agricultural Biotechnology to keep track of all items either reviewed for licence or proposed as research. In addition, the Agriculture Recombinant DNA Committee (ARC) is being disbanded; an Agricultural Biotechnology Recombinant DNA Advisory Committee will now assume responsibility for review of all research projects.

Although the new framework represents a step forward in coordinating federal policy, some worry that the regulatory system is still chaotic. Quick to acknowledge the magnitude of the task Sue Tolin, co-chair of the USDA ARC, is unconvinced that the new framework will sort out all the regulatory tangles now confronting biotechnology research firms. She points to a discouraging catch-22 situation; to prove organisms are safe, they must be tested, but before they can be tested they have to be proven safe.

Meanwhile, the first attempts at actually field-testing a genetically engineered organism are still running into problems. The Environmental Protection Agency declined to issue an experimental use permit to Monsanto to test two strains of Pseudomonas fluorescens containing a gene insertion of a toxic gene from the microbial insecticide Bacillus thuringiensis. The agency wants to see additional data on the organisms' environmental impact and short-term pathogenicity.

Joseph Palca 